\title{
Klasifikasi Nada Sesuai Kodàly Handsign Dengan Metode K-Nearest Neighbor Pada Leap Motion Controller
}

\author{
Muhammad Croassacipto ${ }^{\# 1}$, Muhammad Ichwan ${ }^{* 2}$, Dina Budhi Utami ${ }^{\# 3}$ \\ \# Teknik Informatika, Institut Teknilogi Nasional \\ Jl. PKH Mustopha No.23, Neglasari, Cibeunying Kaler, Jawa Barat 40124, Indonesia \\ ${ }^{1}$ muh.croassacipto@gmail.com \\ ${ }^{2}$ michwan86@gmail.com \\ ${ }^{3}$ dinabusoft@gmail.com
}

\begin{abstract}
Hands can produce a variety of poses in which each pose can have a meaning or purpose that can be used as a form of communication determined according to general agreement or who communicate. Hand pose can be used as a human interaction with computer is faster, intuitive and in line with the natural function of the human body called Handsign. One of them is Kodàly Handsign made by a Hungarian composer named Zoltán Kodály which is a concept in music education in Hungary. This handsign is used in interactive angklung performances in determining the tone that will be played by the K-Nearest Neighbor (KNN) algorithm classification process based on hand poses. This classification process is performed on the extracted data from Leap Motion Controller which takes Pitch, Roll and Yaw values based on basic aircraft principle. The results of the research were conducted 5 times with the value of $\mathrm{k}$ periodically $1,3,5,7,9$ with test data consisting of $1004 \mathrm{Do}, 891 \mathrm{Re}, 526 \mathrm{Mi}, 661 \mathrm{Fa}, 612 \mathrm{Sol}, 913 \mathrm{La}, 702 \mathrm{Si}$ and 874 Do' punctuation on 21099 training data. The test results can recognize hand poses with the optimal $\mathrm{k}$ value $\mathrm{k}=1$ with an accuracy level of $94.87 \%$.
\end{abstract}

Keywords: Classification, K-Nearest Neighbor, Kodàly Handsign, Leap Motion Controller

\begin{abstract}
Abstrak
Tangan dapat menghasilkan berbagai pose di mana setiap pose dapat memiliki makna atau tujuan yang dapat digunakan sebagai bentuk komunikasi ditentukan sesuai kesepakatan umum atau siapa yang berkomunikasi. Pose tangan dapat digunakan sebagai interaksi manusia dengan komputer yang lebih cepat, intuitif dan sesuai dengan fungsi alami dari tubuh manusia yang disebut Handsign. Salah satunya adalah Kodály Handsign yang dibuat oleh seorang komposer Hungaria bernama Zoltán Kodály yang merupakan konsep dalam pendidikan musik di Hungaria. Pendekatan langsung ini digunakan dalam pertunjukan angklung interaktif dalam menentukan nada yang akan dimainkan dengan algoritma K-Nearest Neighbor (KNN) untuk proses klasifikasi berdasarkan pose tangan. Proses klasifikasi ini dilakukan pada data yang diekstrak dari Leap Motion Controller yang mengambil nilai Pitch, Roll dan Yaw berdasarkan prinsip dasar pesawat. Hasil penelitian dilakukan sebanyak 5 kali dengan nilai $\mathrm{k}$ secara periodik 1,3,5,7,9 dengan data uji beruapa pose yang terdiri dari 1004 Do, $891 \mathrm{Re}, 526 \mathrm{Mi}, 661$ Fa, 612 Sol, $913 \mathrm{La}, 702$ Si dan 874 Do' terhadap 21099 data latih. Hasil tes dapat mengenali pose tangan dengan nilai k optimal $\mathrm{k}=1$ dengan tingkat akurasi $94,87 \%$.
\end{abstract}

Kata Kunci: Klasifikasi, K-Nearest Neighbor, Kodàly Handsign, Leap Motion Controller 


\section{PENDAhUluAN}

Angklung merupakan salah satu alat musik tradisional yang berasal dari daerah Jawa Barat yang banyak diminati dari berbagai kalangan usia. Angklung ini dapat dimainkan secara perseorangan atau beramai-ramai secara langsung tanpa latihan terlebih dahulu atau bisa disebut dengan pertunjukkan Angklung Interaktif. Karena dimainkan secara beramai-ramai maka diperlukan metode yang digunakan oleh konduktor untuk mempermudah dalam memimpin pertunjukkan Angklung Intreraktif dalam memberitahu nada yang akan dimainkan kepada pemain angklung yaitu dengan partitur atau dengan handsign (pose tangan). Umumnya menggunakan metode handsign karena metode ini mudah dimengerti. Dimana konduktor akan menggerakkan tangan yang memiliki arti sebuah nada kemudian pemain angklung mengikuti handsign dari konduktor yang kemudian dari sekumpulan nada tersebut akan menghasilkan lagu. Sehingga metode ini diterapkan untuk menentukan nada dalam pertunjukkan Angklung Interaktif.

Dengan menggunakan beberapa peralatan khusus (salah satunya Leap Motion Controller), pose tangan dapat digunakan sebagai interaksi manusia dengan komputer (Computer Human Interaction) untuk memainkan musik tertentu. Tangan dapat menghasilkan berbagai macam pose dimana setiap pose dapat memiliki sebuah arti atau maksud tertentu yang dapat digunakan sebagai salah satu bentuk komunikasi sesuai kesepakatan. Salah satu metode komunikasi menggunakan tangan adalah Kodàly Handsign.

Ada berbagai macam contoh inovasi teknologi dalam interaksi manusia dan komputer seperti gesturetracking dari Leap Motion Controller dan depth-sensing dari Microsoft Kinect. Teknologi tersebut memberikan peluang kepada pengguna untuk berinteraksi dengan komputer menggunakan gerakan tangan atau badan bahkan pose tangan. Selain teknologi-teknologi tersebut, penelitian mengenai penggunaan tangan dalam interaksi manusia dan komputer serta penelitian mengenai pengenalan pose tangan telah banyak diaplikasikan pada beberapa jurnal ilmiah diantaranya yaitu penelitian mengenai pengenalan pose tangan menggunakan metode HuMoment [1]. Selain itu, terdapat penelitian mengenai pengenalan bahasa isyarat yaitu pengenalan American Sign Language (ASL) berdasarkan nilai estimasi pose tangan dari depth-sensor secara realtime [2] dan juga terdapat penelitian mengenai penggunaan tangan sebagai interaksi alamiah dengan Augmented-Reality Interface [3].

Dalam angklung interaktif dimainkan dalam beberapa orang dan apabila terdapat kendala bisa digantikan oleh mesin dimana untuk mesin dapat dikontrol oleh 1 orang. Maka untuk mempermudah dalam memainkan angklung tersebut diperlukan penentuan nada dengan handsign dari visualisasi nada dengan Leap Motion Controller untuk mendapatkan data pose tangan yang dilakukan oleh dirigen dilanjutkan dengan proses klasifikasi menggunakan metode K-Nearest Neighbor (KNN) untuk mengklasifikasikan nada dengan pose tangan sesuai dengan Kodály Handsign.

Penelitian ini difokuskan pada pembangunan sistem pengenalan pose tangan berdasarkan gesture-tracking yang didapatkan dari Leap Motion Controller. Perbedaan dengan penelitian sebelumnya adalah sistem pengenalan gerakan tangan berdasarkan pada posisi skeleton keseluruhan tubuh bukan pada posisi skeleton tangan. Pada penelitian ini, sistem pengenalan pose tangan menggunakan algoritma K-Nearest Neighbor (KNN). KNN dilakukan dengan mencari kelompok k objek dalam data latih yang paling dekat (mirip) dengan objek pada data baru atau data uji. Penggunaan KNN telah digunakan dalam berbagai penelitian dalam area pengenalan objek, salah satunya adalah penggunaan KNN pada pengembangan pengenalan Arabic Sign Language [4]. 


\section{Metode PENELITIAN}

Masukan pada sistem pengenalan pose jari tangan adalah gesture-tracking yang didapat dari skeletontracking pada sensor Leap Motion Controller yang setiap posenya sesuai dengan Kodály Handsign. Dari data gesture-tracking didapat nilai Pitch, Roll, Yaw kemudian diklasifikasikan dengan algoritma K-Nearest Neighbor dimana terdapat 2 alur proses, yaitu proses pelatihan dan proses pengenalan dapat dilihat pada Gambar 1.

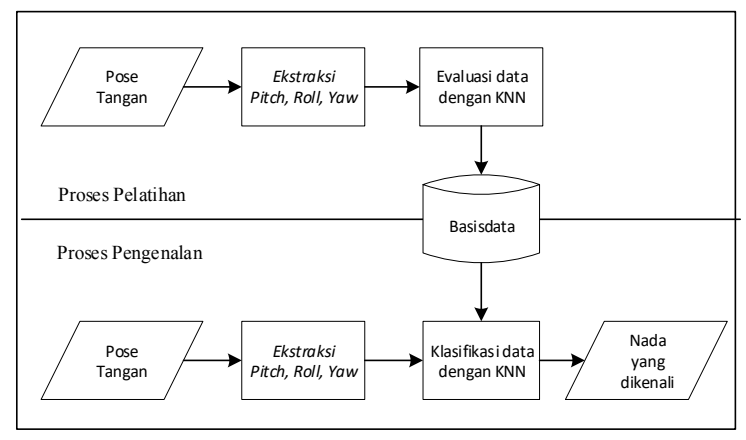

Gambar 1. Blok Diagram Sistem

Proses pelatihan merupakan proses pengumpulan data sampel pose tangan yang ditangkap dengan Leap Motion Controller, kemudian diekstraksi nilai Pitch, Roll, Yaw. Data latih ini kemudian dievaluasi menggunakan algoritma KNN untuk memvalidasi data latih jika hasil evaluasi menyatakan data valid maka data disimpan sebagai referensi untuk proses pengenalan.

Proses pengenalan dimulai dengan pengambilan data uji. Proses pengambilan data uji pose tangan ditangkap dengan Leap Motion Controller, kemudian diekstraksi nilai Pitch, Roll, Yaw. Dengan menggunakan algoritma KNN kemudian data tersebut diklasifikasikan kedalam nada berdasarkan data latih yang disimpan sebelumnya. Hasil dari proses ini berupa nada yang memiliki kedekatan nilai dengan data latih.

\section{A. Kodály Handsign}

Pada Gambar 2 merupakan Kodály Handsign yang dibuat seorang komposer asal Hungaria yang bernama Zoltán Kodály yang merupakan konsep dalam edukasi musik di Hungaria. Metode ini diadopsi dari Curwen's Solfege handsign yang digagaskan oleh John Curwen[5].

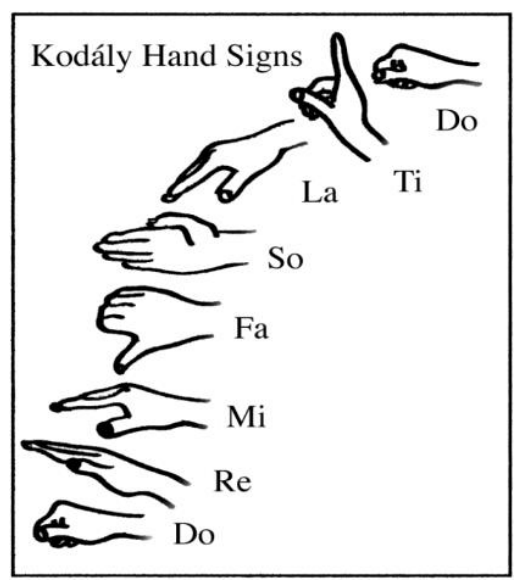

Gambar 2. Kodaly Handsign [11] 
Muhammad Croassacipto et.al.

\section{B. Ekstrasi Data dari Leap Motion Controller}

Leap Motion Controller adalah sebuah perangkat yang dikembangkan oleh Perusahaan Leap Motion. Perangkat ini mendeteksi tangan dan jari sesuai dengan posisi dan gerakannya secara realtime. Perangkat ini beroperasi pada jarak dekat pada tingkat $200 \mathrm{fps}$ (Frame per Second). Sudut pandang dari perangkat ini adalah piramida terbalik dengan luas sekitar 8 kubik kaki yang berpusat pada perangkat [6]. Rentang efektif dari alat ini memanjang dari sekitar 1 inci hingga 2 kaki diatas perangkat. Perangkat ini menggunakan 2 kamera inframerah dengan tingkat presisi tinggi dan 3 LED untuk menangkap informasi tangan dalam rentang aktifnya. Akan tetapi, informasi ini tidak memberikan gambar tangan yang terdeteksi. Informasi tersebut berasal dari pengolahan data yang diperoleh, ekstrak posisi, dan informasi lainnya menggunakan matematika kompleks [8]. Gambar 3 menunjukkan gambaran skematik dari Leap Motion Controller [6]. Perangkat ini menggunakan sistem koordinat Cartesian tangan kanan seperti yang ditunjukkan pada Gambar 4. Nilai yang dihasilkan dalam satuan milimeter dunia nyata. The Origin adalah pusat perangkat. Sumbu $\mathrm{x}$ dan $\mathrm{z}$ terletak pada bidang horizontal, dengan sumbu x berjalan sejajar dengan tepi panjang perangkat. Sumbu y vertikal, dengan nilai positif meningkat ke atas. Sumbu z memiliki nilai positif yang semakin menjauh dari layar komputer [7]. Karena perangkat melacak tangan dan jari-jari dalam bidang pandangnya, ia menyediakan pembaruan sebagai satu set, atau bingkai data. Setiap frame berisi daftar data pelacakan dasar yang menggambarkan gerakan keseluruhan dalam adegan. Ketika mendeteksi tangan dan jari-jari, perangkat lunak Leap Motion Controller memberikannya tag ID unik. ID tetap sama selama entitas tersebut tetap terlihat dalam bidang tampilan perangkat. Jika pelacakan hilang dan kembali, perangkat lunak dapat menetapkannya sebagai ID baru.[9]

Selanjutnya ekstraksi data yang akan diklasifikasi dari Leap Motion Controller pada Gambar 4, yaitu nilai data tangan kanan pada Gambar 5 (Leap Motion Visualizer) untuk penentuan nada yang terdiri dari Pitch, Roll, Yaw pada Gambar 6 yang didapat dari hand orientation tracking berdasarkan palm normal pada Gambar 7.

Nilai Pitch, Roll, Yaw diambil berdasarkan prinsip gerak dasar pesawat. Pitch merupakan gerakan keatas dan kebawah dari hidung pesawat yang bergerak rotasi pada sumbu x. Roll merupakan gerakan berguling yang bergerak rotasi pada sumbu z. Sedangkan Yaw merupakan gerakan ke kanan atau ke kiri dari hidung pesawat yang bergerak rotasi pada sumbu y.

Sama hal dengan tangan maka prinsip gerak pesawat dapat diterapkan untuk melihat arah dan kemiringan tangan.

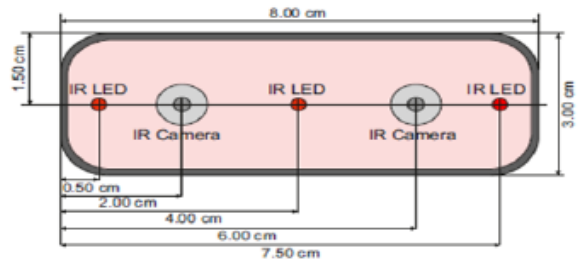

Gambar 3. Skematik Leap Motion Controller [9]

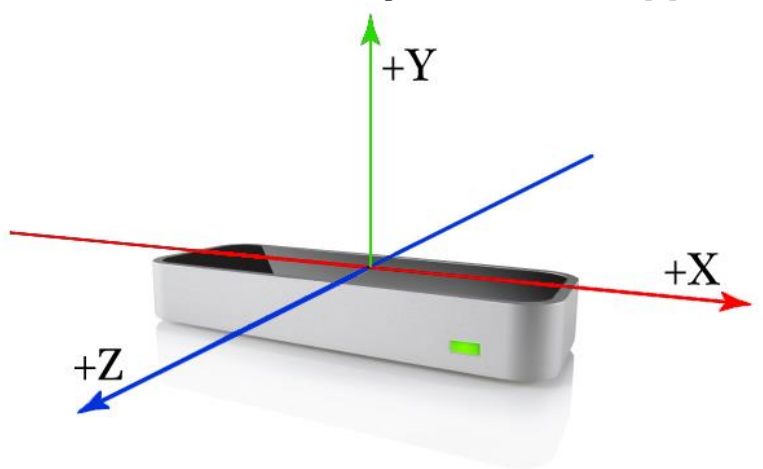

Gambar 4. Leap Motion Controller [7] 


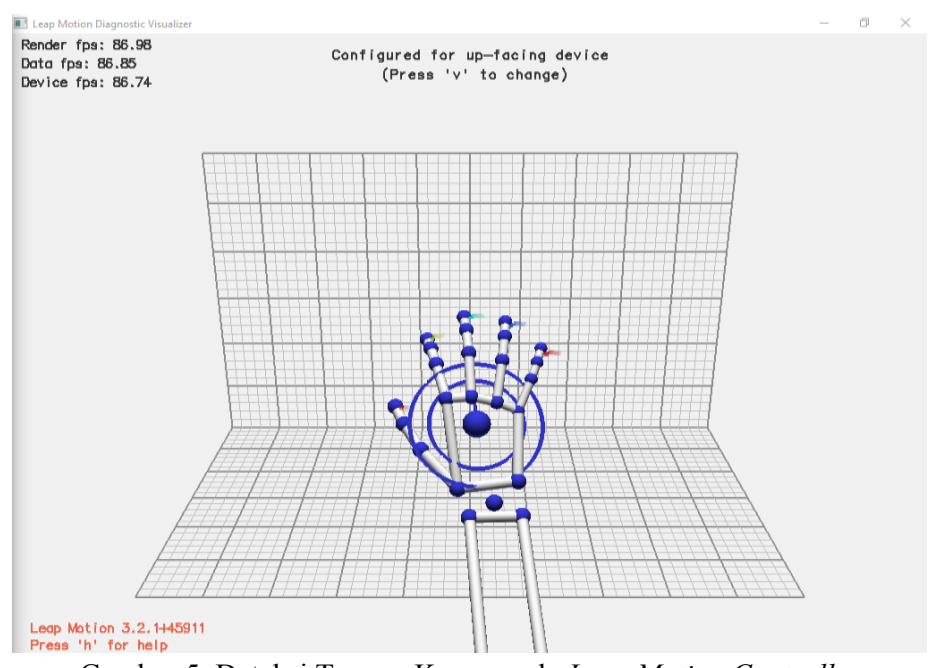

Gambar 5. Deteksi Tangan Kanan pada Leap Motion Controller

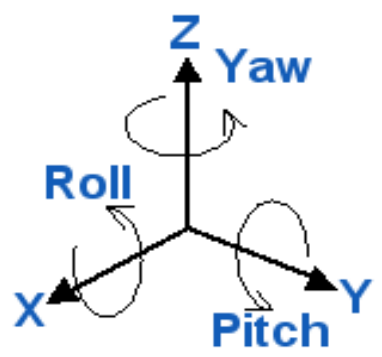

Gambar 6. Pitch, Roll, Yaw [12]

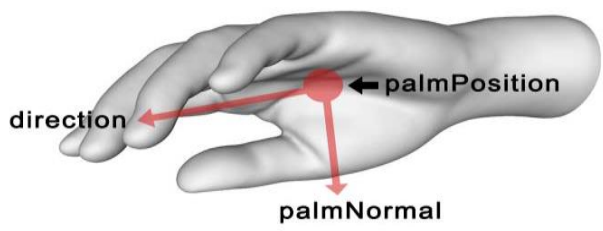

Gambar 7. Palm Normal [13]

C. Klasifikasi K-Nearest Neighbor (KNN)

K-Nearest Neighbor (KNN) adalah metode melakukan klasifikasi terhadap objek berdasarkan data latih yang jaraknya paling dekat dengan objek tersebut [10]. Metode ini bertujuan untuk mengklasifikasikan objek baru berdasarkan atribut dan data latih. Diberikan suatu titik query, selanjutnya akan ditemukan sejumlah K objek atau titik training yang paling dekat dengan titik query. Nilai prediksi dari query akan ditentukan berdasarkan klasifikasi tetanggaan. Dengan nilai k tersebut dapat diprediksi nilai akurasi klasifikasi data uji dengan data latih berdasarkan objeknya.

Dekat atau jauhnya jarak ke tetangga dapat dihitung berdasarkan Euclidean Distance yang dipresentasikan pada persamaan 1 sebagai berikut.

$$
D(a, b)=\sqrt{\sum_{k=1}^{d}\left(a_{k}-b_{k}\right)^{2}}
$$


Muhammad Croassacipto et.al.

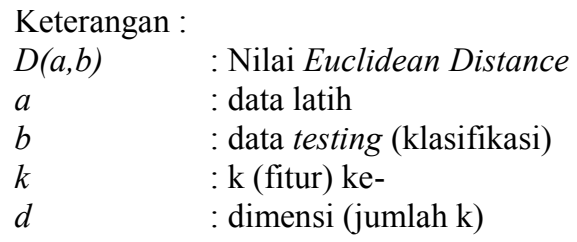

Dimana matriks $D(a, b)$ adalah jarak skalar (Euclidean Distance) dari kedua vektor $a$ dan $b$ dari matriks dengan ukuran $d$ dimensi.

Berikut adalah flowchart proses klasifikasi nada algoritma KNN seperti pada Gambar 8.

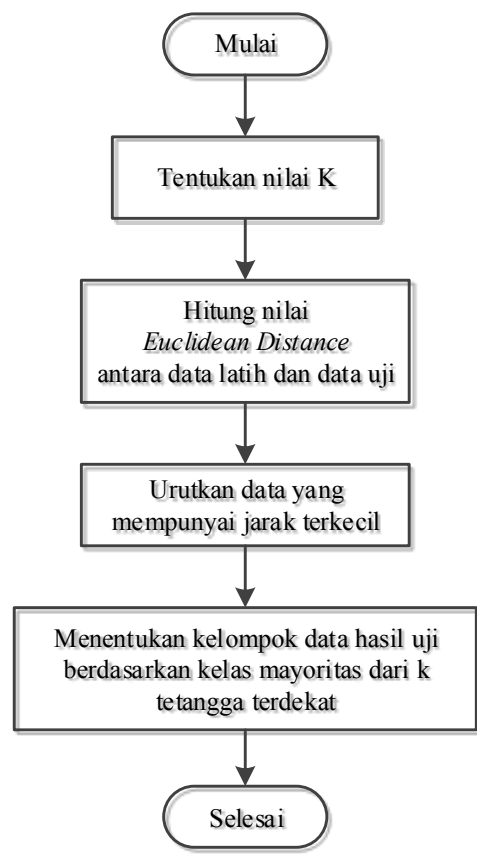

Gambar 8. Flowchart Proses Klasifikasi Nada Algoritma KNN

Dalam menggunakan algogritma KNN terdapat 2 proses, yaitu proses persiapan data latih dan data uji (proses klasifikasi).

I. Proses Persiapan Data Latih

Proses persiapan data latih seperti pada gambar 9 digunakan sebagai parameter untuk menentukan nada sesuai dengan Kodàly Handsign. Dimana akan disimpan beberapa sampel data nilai Pitch, Roll, Yaw kedalam dataset sesuai dengan nadanya.

II. Proses Klasifikasi

Data uji atau proses klasifikasi seperti pada gambar 10 dilakukan dengan membandingkan nilai Pitch, Roll, Yaw yang diterima dengan nilai data latih sebelumnya disimpan di dataset. 


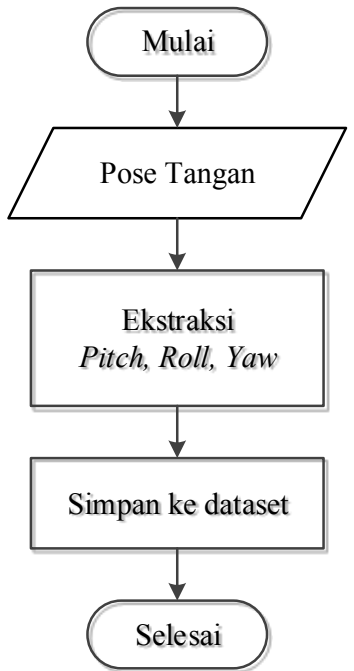

Gambar 9. Proses Persiapan Data Latih

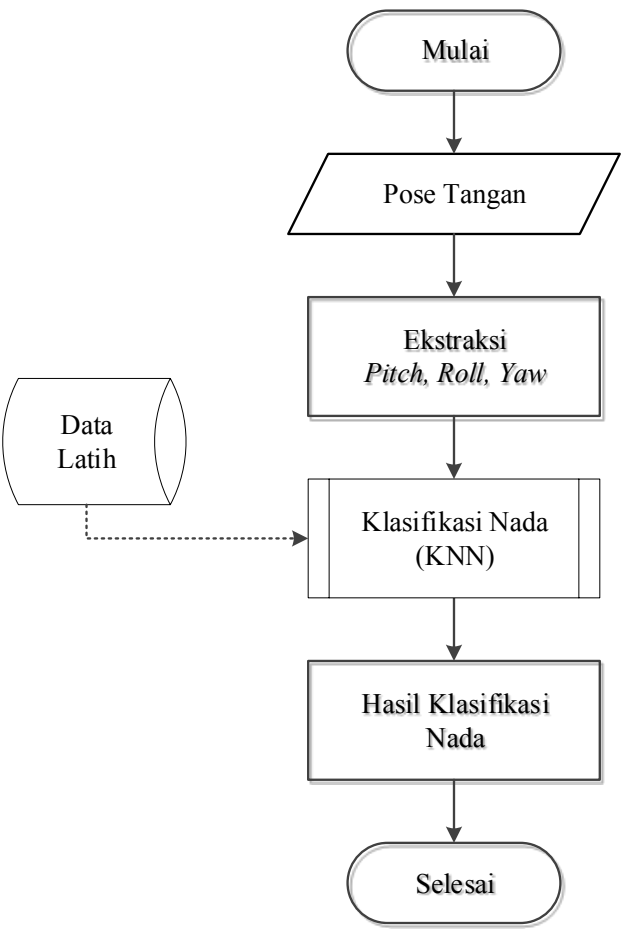

Gambar 10. Proses Klasifikasi

\section{HASIL DAN PEMBAHASAN}

Dari data uji yang didapat terdiri dari 1004 pose nada Do, 891 pose nada Re, 526 pose nada Mi, 661 pose nada Fa, 612 pose nada Sol, 913 pose nada La, 702 pose nada Si dan 874 pose nada Do' terhadap 21099 data latih yang sudah dikasifikasikan berdasarkan nada. Dilakukan pengujian dengan algoritma K-Nearest Neighbor dengan nilai $\mathrm{k}$ yang ditentukan secara berkala yakni 1, 3, 5, 7, 9. Berikut adalah hasil dari pengujian yang dilakukan pada klasifikasi nada terhadap k yang telah ditentukan. 
Tabel 1. Hasil Pengujian dengan k=1.

\begin{tabular}{|c|c|c|c|c|c|c|}
\hline \multirow[b]{2}{*}{ No } & \multirow[b]{2}{*}{ Nada } & \multirow{2}{*}{$\begin{array}{l}\text { Jumlah } \\
\text { data uji }\end{array}$} & \multicolumn{2}{|c|}{ Klasifikasi } & \multirow[b]{2}{*}{ Akurasi } & \multirow[b]{2}{*}{ Error } \\
\hline & & & Sesuai & $\begin{array}{l}\text { Tidak } \\
\text { Sesuai }\end{array}$ & & \\
\hline 1 & Do & 1004 & 831 & 173 & $82.77 \%$ & $17.23 \%$ \\
\hline 2 & $\operatorname{Re}$ & 891 & 679 & 212 & $76.21 \%$ & $23.79 \%$ \\
\hline 3 & $\mathrm{Mi}$ & 526 & 526 & 0 & $100.00 \%$ & $0.00 \%$ \\
\hline 4 & $\mathrm{Fa}$ & 661 & 661 & 0 & $100.00 \%$ & $0.00 \%$ \\
\hline 5 & Sol & 612 & 612 & 0 & $100.00 \%$ & $0.00 \%$ \\
\hline 6 & $\mathrm{La}$ & 913 & 913 & 0 & $100.00 \%$ & $0.00 \%$ \\
\hline 7 & $\mathrm{Si}$ & 702 & 702 & 0 & $100.00 \%$ & $0.00 \%$ \\
\hline 8 & Do' & 874 & 874 & 0 & $100.00 \%$ & $0.00 \%$ \\
\hline \multicolumn{5}{|c|}{ Rata-Rata } & $94.87 \%$ & $5.13 \%$ \\
\hline
\end{tabular}

Tabel 2. Hasil Pengujian dengan k=3.

\begin{tabular}{|c|c|c|c|c|c|c|}
\hline \multirow[b]{2}{*}{ No } & \multirow[b]{2}{*}{ Nada } & \multirow{2}{*}{$\begin{array}{l}\text { Jumlah } \\
\text { data uji }\end{array}$} & \multicolumn{2}{|c|}{ Klasifikasi } & \multirow[b]{2}{*}{ Akurasi } & \multirow[b]{2}{*}{ Error } \\
\hline & & & Sesuai & $\begin{array}{l}\text { Tidak } \\
\text { Sesuai }\end{array}$ & & \\
\hline 1 & Do & 1004 & 833 & 171 & $82.77 \%$ & $17.23 \%$ \\
\hline 2 & $\operatorname{Re}$ & 891 & 650 & 241 & $72.95 \%$ & $27.05 \%$ \\
\hline 3 & Mi & 526 & 526 & 0 & $100.00 \%$ & $0.00 \%$ \\
\hline 4 & $\mathrm{Fa}$ & 661 & 661 & 0 & $100.00 \%$ & $0.00 \%$ \\
\hline 5 & Sol & 612 & 612 & 0 & $100.00 \%$ & $0.00 \%$ \\
\hline 6 & $\mathrm{La}$ & 913 & 913 & 0 & $100.00 \%$ & $0.00 \%$ \\
\hline 7 & $\mathrm{Si}$ & 702 & 702 & 0 & $100.00 \%$ & $0.00 \%$ \\
\hline 8 & Do' & 874 & 874 & 0 & $100.00 \%$ & $0.00 \%$ \\
\hline \multicolumn{5}{|c|}{ Rata - Rata } & $94.49 \%$ & $5.51 \%$ \\
\hline
\end{tabular}

Tabel 3. Hasil Pengujian dengan k=5.

\begin{tabular}{|c|c|c|c|c|c|c|}
\hline \multirow[b]{2}{*}{ No } & \multirow[b]{2}{*}{ Nada } & \multirow{2}{*}{$\begin{array}{l}\text { Jumlah } \\
\text { data uji }\end{array}$} & \multicolumn{2}{|c|}{ Klasifikasi } & \multirow[b]{2}{*}{ Akurasi } & \multirow[b]{2}{*}{ Error } \\
\hline & & & Sesuai & $\begin{array}{l}\text { Tidak } \\
\text { Sesuai }\end{array}$ & & \\
\hline 1 & Do & 1004 & 833 & 171 & $82.77 \%$ & $17.23 \%$ \\
\hline 2 & $\operatorname{Re}$ & 891 & 532 & 359 & $59.71 \%$ & $40.29 \%$ \\
\hline 3 & $\mathrm{Mi}$ & 526 & 526 & 0 & $100.00 \%$ & $0.00 \%$ \\
\hline 4 & $\mathrm{Fa}$ & 661 & 661 & 0 & $100.00 \%$ & $0.00 \%$ \\
\hline 5 & Sol & 612 & 612 & 0 & $100.00 \%$ & $0.00 \%$ \\
\hline 6 & $\mathrm{La}$ & 913 & 913 & 0 & $100.00 \%$ & $0.00 \%$ \\
\hline 7 & $\mathrm{Si}$ & 702 & 702 & 0 & $100.00 \%$ & $0.00 \%$ \\
\hline 8 & Do' & 874 & 874 & 0 & $100.00 \%$ & $0.00 \%$ \\
\hline \multicolumn{5}{|c|}{ Rata - Rata } & $92.83 \%$ & $7.17 \%$ \\
\hline
\end{tabular}


Tabel 4. Hasil Pengujian dengan $\mathrm{k}=7$.

\begin{tabular}{|c|c|c|c|c|c|c|}
\hline \multirow[b]{2}{*}{ No } & \multirow[b]{2}{*}{ Nada } & \multirow{2}{*}{$\begin{array}{l}\text { Jumlah } \\
\text { data uji }\end{array}$} & \multicolumn{2}{|c|}{ Klasifikasi } & \multirow[b]{2}{*}{ Akurasi } & \multirow[b]{2}{*}{ Error } \\
\hline & & & Sesuai & $\begin{array}{c}\text { Tidak } \\
\text { Sesuai } \\
\end{array}$ & & \\
\hline 1 & Do & 1004 & 831 & 173 & $82.77 \%$ & $17.23 \%$ \\
\hline 2 & $\mathrm{Re}$ & 891 & 516 & 375 & $57.91 \%$ & $42.09 \%$ \\
\hline 3 & Mi & 526 & 526 & 0 & $100.00 \%$ & $0.00 \%$ \\
\hline 4 & $\mathrm{Fa}$ & 661 & 661 & 0 & $100.00 \%$ & $0.00 \%$ \\
\hline 5 & Sol & 612 & 612 & 0 & $100.00 \%$ & $0.00 \%$ \\
\hline 6 & $\mathrm{La}$ & 913 & 913 & 0 & $100.00 \%$ & $0.00 \%$ \\
\hline 7 & $\mathrm{Si}$ & 702 & 702 & 0 & $100.00 \%$ & $0.00 \%$ \\
\hline 8 & Do' & 874 & 874 & 0 & $100.00 \%$ & $0.00 \%$ \\
\hline \multicolumn{5}{|c|}{ Rata - Rata } & $92.75 \%$ & $7.25 \%$ \\
\hline
\end{tabular}

Tabel 5. Hasil Pengujian dengan k=9.

\begin{tabular}{|c|c|c|c|c|c|c|}
\hline \multirow[b]{2}{*}{ No } & \multirow[b]{2}{*}{ Nada } & \multirow{2}{*}{$\begin{array}{l}\text { Jumlah } \\
\text { data uji }\end{array}$} & \multicolumn{2}{|c|}{ Klasifikasi } & \multirow[b]{2}{*}{ Akurasi } & \multirow[b]{2}{*}{ Error } \\
\hline & & & Sesuai & $\begin{array}{l}\text { Tidak } \\
\text { Sesuai }\end{array}$ & & \\
\hline 1 & Do & 1004 & 832 & 172 & $82.87 \%$ & $17.13 \%$ \\
\hline 2 & $\mathrm{Re}$ & 891 & 527 & 364 & $59.15 \%$ & $40.85 \%$ \\
\hline 3 & $\mathrm{Mi}$ & 526 & 526 & 0 & $100.00 \%$ & $0.00 \%$ \\
\hline 4 & $\mathrm{Fa}$ & 661 & 661 & 0 & $100.00 \%$ & $0.00 \%$ \\
\hline 5 & Sol & 612 & 612 & 0 & $100.00 \%$ & $0.00 \%$ \\
\hline 6 & $\mathrm{La}$ & 913 & 913 & 0 & $100.00 \%$ & $0.00 \%$ \\
\hline 7 & $\mathrm{Si}$ & 702 & 702 & 0 & $100.00 \%$ & $0.00 \%$ \\
\hline 8 & Do' & 874 & 874 & 0 & $100.00 \%$ & $0.00 \%$ \\
\hline \multicolumn{5}{|c|}{ Rata - Rata } & $92.59 \%$ & $7.41 \%$ \\
\hline
\end{tabular}

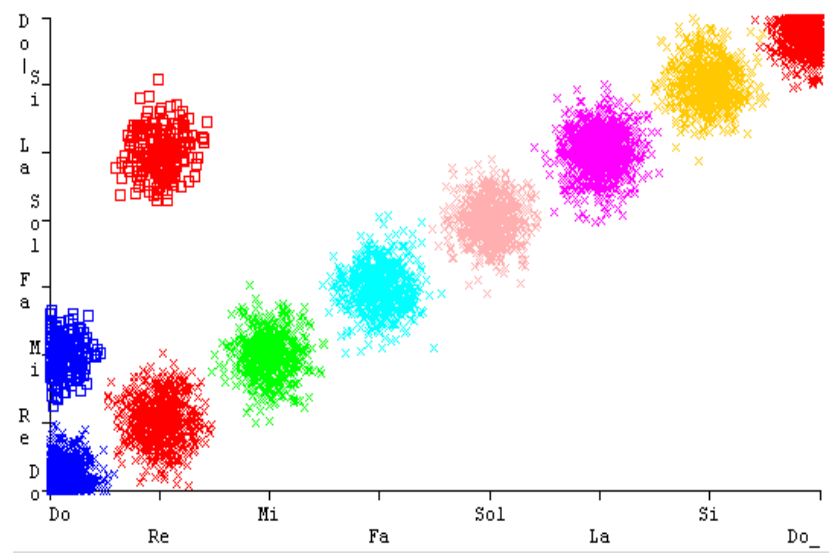

Gambar 11. Visualisasi Klasifikasi Nada dengan K-Nearest Neighbor

Berdasarkan hasil pengujian pada Tabel 1, Tabel 2, Tabel 3, Tabel 4 dan Tabel 5 sesuai dengan $\mathrm{k}$ yang telah ditentukan maka didapat bahwa nilai $\mathrm{k}$ optimal yakni pada $\mathrm{k}=1$ dengan akurasi $94,87 \%$ sebagaimana divisualisasikan pada Gambar 11 untuk setiap nada. Dimana untuk nada Do terdapat 831 data yang sesuai dan 173 data tidak sesuai (mirip dengan nada Mi) dari 1004 data sedangkan nada Re terdapat 679 data yang sesuai dan 212 data yang tidak sesuai (mirip dengan nada La). 
Muhammad Croassacipto et.al.

\section{KESIMPULAN}

Berdasarkan hasil penelitian, sistem pengenalan pose tangan menggunakan algoritma $K$-Nearest Neighbor

dapat mengenali pose tangan dengan nilai k optimal k=1 dengan tingkat akurasi pengenalan $94.87 \%$. Sistem dapat mengenali pose tangan dalam menentukan nada sesuai dengan Kodaly Handsign berdasarkan Pitch, Roll, Yaw dari Leap Motion Controller. Selain itu, sistem dapat mengenali pose tangan walaupun dilakukan perubahan perubahan posisi.

\section{REFERENCES}

[1] Utami Dina Budhi, Ichwan Muhammad, "Pengenalan Pose Tangan Menggunakan HuMoment". JURNAL INFOTEL, [S.1.], v. 9, n. 1, p. 100-107, Feb. 2017. ISSN 2460-0997.

[2] C. Keskin, F. Kirac, Y.E. Kara, L. Akarun, "Real Time Hand Pose Estimation Using Depth Sensors". Computer Vision Workshops (ICCV Workshop) 2011 IEEE International Conference on, pp. 1228-1234, 2011.

[3] Mark Billinghurst, Tham Piumsomboon, dan Huidong Bai, "Hands in Space: Gesture Interaction with Augmented-Reality Interfaces", IEEE Computer Graphics and Applications, vol. 34, Issue: 1, Jan.-Feb. 2014, pp. 77 - 80, 2014.

[4] S. J. Reyadh Naoum, Hussein H. Owaied, "Development of a new arabic sign language recognition using k-nearest neighbor algorithm," Journal of Emerging Trends in Computing and Information Sciences, vol. 3, pp. 1173-1178, 2012.

[5] Choksy, L. (1999). The Kodály method I (3rd ed.). Upper Saddle River, NJ: Prentice Hall.

[6] F. Weichert, D. Bachmann, B. Rudak, and D. Fisseler, "Analysis of the accuracy and robustness of the leap motion controller," Sensors (Basel, Switzerland), vol. 13, no. 5, p. 6380, 2013.

[7] https://developer.leapmotion.com/documentation.

[8] https://forums.leapmotion.com.

[9] Mohandes Mohamed, Oladimeji Salihu, Deriche Mohamed. (2014). "Arabic Sign Language Recognition using the Leap Motion Controller". IEEE International Symposium on Industrial Electronics. 10.1109/ISIE.2014.6864742.

[10] Dedy Yuristiawan. 2015. "Identifikasi Kualitas Daging Sapi Berbasis Android Dengan Ekstraksi Fitur Warna Dan Klasifikasi KNN ". Fakultas Ilmu Komputer, Universitas Dian Nuswantoro.

[11] Kaii Lee. “The Star-Spangled Banner”. (2014, August). Available : https://www.kafm.net/StarSpangledBanner/SSB.html.

[12] Hall, Carrie. (2018). Manufacturing a Calibration Device for Orientation Sensors.

[13] Go Ando. “LEAP MOTION + openFrameworks 手のモデル解説”. (2013, July). Available : http://gndo.blogspot.com/2013/07/leap-motion-openframeworks 30.html. 